\title{
LOCAL PUBLIC FINANCES IN THE CONTEXT OF THE FINANCE LAW SUBJECT
}

At the current stage of the law development, both Ukrainian and Russian researchers in the field of financial law are positive that the finance law is a public field of law that regulates public relations ${ }^{1}$. While considering the public law, the theorists conclude that it should be defined as a legal subsystem that presents state, international and social interests. At the same time, the subject of the public law regulation alters a little because of the need to regulate the new entities that appear in modern society (self-government, parties, social associations etc.). The inclusion of the relations which appeared because of the mobilization, distribution and use of the local self-government bodies' money funds means the broadening of the financial law subject ${ }^{2}$. All these factors generated the following questions: What are the public finances? Do the self-government bodies' finances belong to the public finances and public relations?

In general, according to A.A. Nechay, the public finances are social relations connected with the satisfaction of the public interest of all kinds ${ }^{3}$. They appear in the process of formation, distribution (re-distribution) and use of the state and self-government bodies' money funds and the funds that satisfy social interests,

1 Воронова Л.К., Фінансове право України. (Kyiv: Precedent, My Book, 2006), Р. 36; Бех Г.В., Дмитрик О.О., Криницький І.Є., Фінансове право, (Kyiv: Yurincom Inter, 2004), Р. 39; Орлюк О.П. Фінансове право (Kyiv: Yurincom Inter, 2003), Р. 22; Химичева Н.И., Финансовое право, 2d ed. (Moskow: Yurist, 1999), Р. 37.

2 Нечай А. Фінансова діяльність держави та фінансове право в сучасний період: їх поняття, «Право України», 2000, № 1, P. 56.

3 In the modern theory of the finance law, we can come across such a category as "publicity" and "public interest". According to A. Nechay, "public interest" is the interest that serves as the criterion of the public and private law differentiation. State interests, legal status of the state bodies, authorities and the regulation of the social relations play a great role for the public law. The private law has the deal with the interests of a particular person. See Нечай A.A. . Проблеми правового регулювання публічних фінансів та публічних видатків (Chernivtsy: Ruta, 2004), P. 29). The public interest according to N.Yu. Pryshva, is: 1) the concentrated expression of the general social needs and pursuits; 2) the recognized by the state and secured with the law social interest, the satisfaction of which is the condition and guarantee of the social unity existence and development. See Пришва Н.Ю. Правове регулювання публічних доходів «Вісник Київського національного університету. Юридичні науки», 2005, №63-64, Р. 71). See also Музика О.А. Категорія «публічність» у фінансовому праві «Фінансове право», 2007, № 1, Р. 25-30. 
recognized by the state or by the self-government bodies regardless of the property form of such funds ${ }^{4}$. Thus, this definition specifies both state and local finances.

The essence of the relations regulated by the financial law is rather different. The reason is the multilink financial system of Ukraine and the participants of this legal structure. The subject and notion of the financial law are connected both with state and local finances. The exclusion of the relations concerning the local finances, would contradict the unity of the financial system as well as the unified financial, credit and monetary policy. The state and local finances (and relations which seem to concern them) have the same public character and are classified as centralized and decentralized.

During the Soviet period the state finances were privileged. The local finances as a kind of a local self-government were simply denied (they were considered as a part of the state finances). In such a situation, the subject of the financial law covered only the relations to the financial activity of the state. Nevertheless, the nowadays development of commodity-money, economic and social relations has caused a progress in the financial relationship not only at the state level but at the local level as well. All this changes have caused the alteration of the financial law subject. Today, some financial relations have become part of the private financial sector. As a result, these relations became an object of either civil or private law. The other part of the private finances is involved in the field of the state finances through different obligatory payments and assessments. This causes the broadening of the state finance influence and, correspondingly, the subject of the finance law ${ }^{5}$.

It should be noted, that local finances and financial basis of the local selfgovernment are very often understood as a municipal law institution. Thus, the municipal law regulates the relations in this field. The development of the Ukrainian legal system contributes to the formation of new areas of law. But there is still a discussion among lawyers whether to separate the public law as an independent field of law, the so-called municipal law, which regulates social relations that appear in the process of the local self-government organization and activity.

Financial activities of the local self-government are certainly an expression of public interest. Therefore, local self-government money funds (local finances) and the structure based on these funds are also public. Thus, as A.A. Nechuy points out, the legal regulation of local self-government bodies' financial activities forms the

Нечай А.А. Проблеми правового регулювання публічних фрінансів та публічних видатків (Chernivtsy: Ruta, 2004), P. 61.

5 Заверуха О.Б. До питання про поняття бюджетних повноважень органів місцевого самоврядування «Держава і право: Збірник наукових праць. Юридичні та політичні науки». №8. - (Kyiv, Institute of State and Law named by V.M. Koretsky of National Academy of Science of Ukraine), 2000, P. 268. 
subject of public and not private law ${ }^{6}$. The author of the cited article raises the issue if it is rightful to speak about the appearance of a new "municipal finance law" and presents some arguments against it. Thus, the essence and the aim of the local selfgovernment bodies' activity is the formation of the public funds and the bearing of the expenses that are needed both for the fulfillment of the self-government functions and for the territorial (public) interest satisfaction. The subject and the method of the relation regulation have all the characteristics that are inherent in the financial law. Thus, the subject of the regulations of the financial law should include both the local and the state finances.

A great number of the municipal legal regulations concerning property, financial, land and other relations at the local level can be the regulations of the civil, finance, land or other areas of law, according to Fadeev V.I. ${ }^{7}$. Hence, this new "area" of law is a public-private law, which uses the regulations of the other fields of law for the absence of its own. Thus, the municipal law regulations cannot even in part govern the relations that make up the subject of the aforesaid area. It seems that the local finances (from the point of view of the legal regulation) cannot be referred to the complex municipal law that has the qualities of private and public-private regulations.

On the grounds of the above-mentioned reasons, it can asserted that the state and the local public finances are inseparably linked together in the aspect of the financial law but not of the municipal or some other areas of law.

Нечай А. Фінансова діяльність держави та фінансове право в сучасний період: їх поняття. « Право України», 2000, № 1, Р. 57.

7 Кутафин О.Е., Фадеев В.И., Муниципальное право Росийской Федерации, 2d ed. (Moskow, Yurist, 2000), P. 12.; See Погорілко В.Ф., Фрицький О.Ф., Муніципальне право України (Kyiv: Yurincom Inter, 2001), Р. 7. 


\section{Streszczenie}

Współczesne prawo finansowe podlega ciagłym procesom rozwoju. Jednym z jego czynników jest coraz większy udział samorządów lokalnych w pozyskiwaniu i dystrybucji środków finansowych. Niniejszy artykuł został poświęcony teoretycznym i praktycznym problemom dotyczącym przepisów regulujących finanse publiczne na Ukrainie. Autorka analizje m.in. definicję finansów publicznych, ich miejsce w prawie finansowym oraz podnosi problemy finansów lokalnych. 